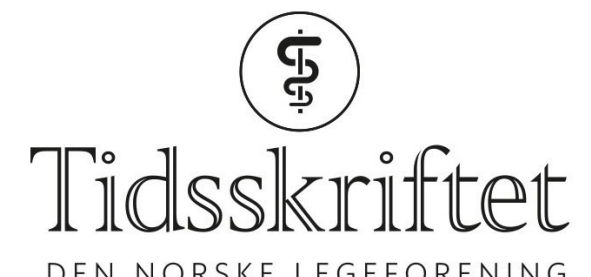

DEN NORSKE LEGEFORENING

\title{
Hvorfor skriver vi ikke «jeg» i journalen?
}

SPRÅKSPALTEN

\section{HILDE VIGDIS LARSEN}

E-post: hildevigdis@hotmail.com

Hilde Vigdis Larsen (f. 1981) er lege i spesialisering ved Anestesi- og intensivavdelingen, Sykehuset Namsos.

Hvorfor er det en sterk tradisjon blant legerfor å unngå ordet «jeg» i pasientjournalene?

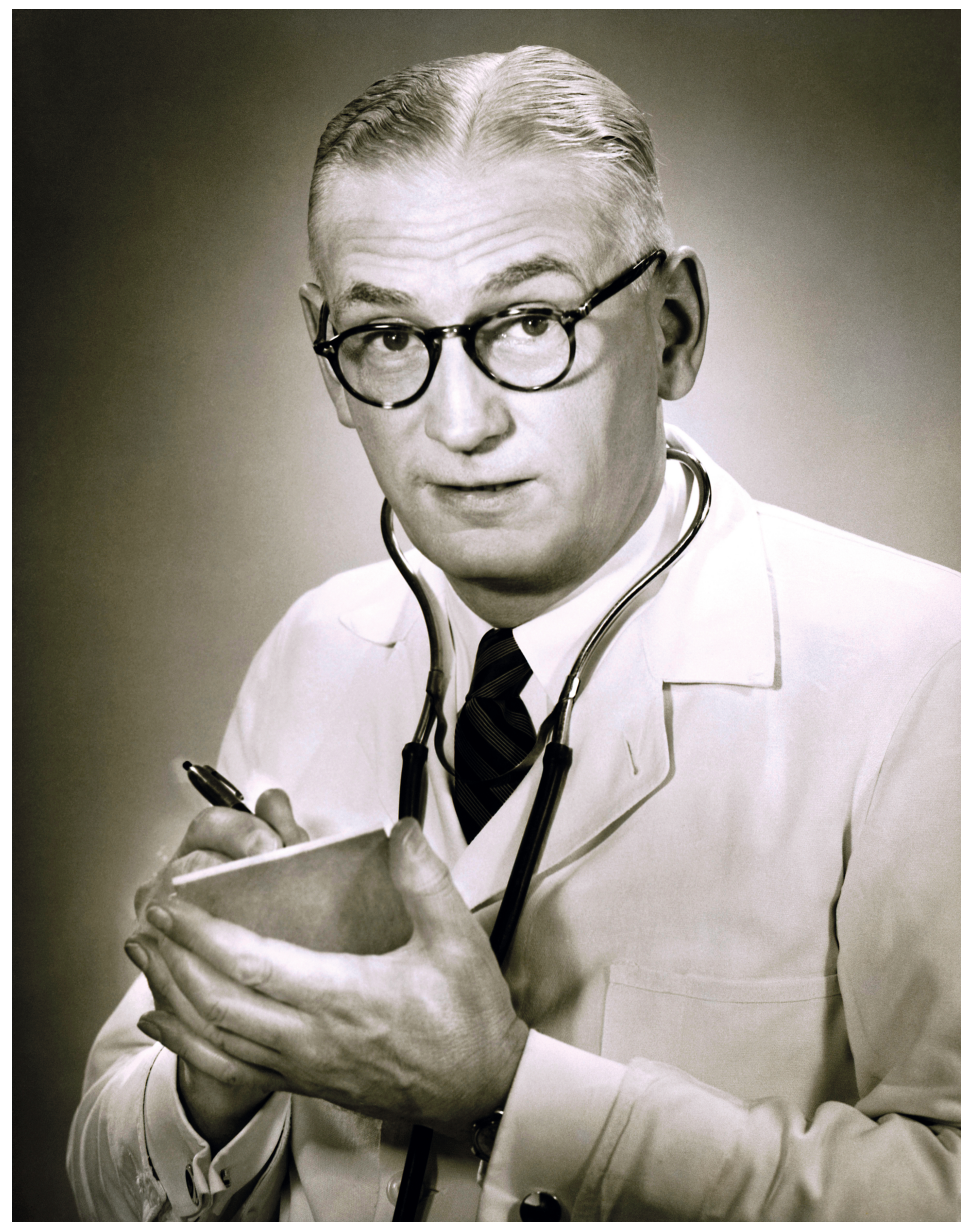

Illustrasjonsfoto: iStock

Omskrivninger som «undertegnede», «man», «en», «vi», «det vurderes dit hen at...» og lignende florerer. Jeg synes dette kompliserer språket unødvendig, i verste falltåkelegger det hvem som er ansvarligfor en vurdering. 
Jeg opplever at yngre leger gjennomgående angir presist hvem de har konferert med for å komme frem til en beslutning, mens overleger har en tendens til å bruke «man» o.l., ogsåder det er åpenbart at det kun er forfatteren av notatet som har stått for vurderingen eller prosedyren.En kollega har foreslått at hensikten meddenne tradisjonen kan være å uttrykke en form for beskjedenhet.

Jeghar selvbegynt konsekventå bruke "jeg» i notater nårjeg personligstår bakvurderingen eller prosedyren som er utført, noe jeg synes forenkler og forbedrer språket i notatene mine, men jeg unnslipper ikke helt følelsen av å avvike fra en språklig tradisjon som jeg ikke helt forstår bakgrunnen for.

Håper språkspalten kan forklare denne tradisjonen!

Les svaret til Erlend Hem.

Publisert: 18. september 2017. Tidsskr Nor Legeforen. DOI:10.4045/tidsskr.17.06o6

(C) Tidsskrift for Den norske legeforening 2020. Lastet ned fra tidsskriftet.no 